\title{
Serotonin and embolization by small blood clots in dogs
}

\author{
R OBERT MAR SHA L L \\ From the Nuffield Department of Surgery, Radcliffe Infirmary, Oxford
}

Serotonin is one of the few substances which has a strong vasoconstrictor action on the pulmonary circulation; it can also cause bronchoconstriction. Serotonin in the blood is contained almost entirely in the platelets, but this is released during the process of clot formation. Several investigators (Comroe, van Lingen, Stroud, and Roncoroni, 1953 ; Smith and Smith, 1955 ; Cobb and Nanson, 1960) have suggested that serotonin may be responsible for many of the effects of embolization of the lungs by blood clot or thrombus.

The present experiments were carried out to investigate further the role of serotonin in the effect of small blood clot emboli on anaesthetized dogs. Normal blood clots and serotonin-depleted clots have been injected into normal dogs, and autogenous blood clots have been injected into serotonin-depleted dogs.

\section{METHODS}

Mongrel dogs of $10 \cdot 8$ to $15 \cdot 0 \mathrm{~kg}$. were used in the experiments. Morphine, $1 \mathrm{mg}$. $/ \mathrm{kg}$., was used as a premedication before anaesthesia in dogs 1 and 2 , but this was omitted from later experiments since morphine may liberate histamine from the tissues (Nasmyth and Stewart, 1950).

SEROTONIN-DEPLETION OF INJECTED BLOOD CLOTS The serotonin stores of the body can be depleted by treatment of the animal with reserpine (Haverback, Dutcher, Shore, Tomich, Terry, and Brodie, 1957 ; Shore, Pletscher, Tomich, Carlsson Kuntzman, and Brodie, 1957). Blood with a low serotonin content was obtained by giving a dog a single dose of $20 \mathrm{mg}$. reserpine approximately 16 hours before the start of the main experiment. Before giving the reserpine blood samples were taken for estimation of initial serotonin levels.

SEROTONIN DEPLETION OF RECIPIENT DOGS To three dogs $1 \mathrm{mg}$. reserpine was given by mouth daily for six to eight days. This quantity of reserpine was sufficient to deplete the blood of serotonin and had less severe systemic effects than the large single dose. 웅

ASSAY OF SEROTONIN The assay was carried out on atropinized rat colon by the method of Humphrey and Toh (1954). The serum was separated after $\vec{\varphi}$ incubation of the blood for four hours at $37^{\circ} \mathrm{C}$. and $\mathscr{\odot}$ was stored frozen until assayed, usually on the following day. The serotonin was released from the platelets of the whole blood by freezing and thawing three times, but on assay the blood appeared to contain only about half as much serotonin as the serum. The blood had been collected into ethylene diamine $\mathbb{Q}$ tetracetate (EDTA) bottles and towards the end of $\varrho$ the series it was discovered that EDTA inhibited the $\overrightarrow{\overrightarrow{0}}$ contraction of rat colon. Further experiments showed 3 that the serotonin content of the serum from blood incubated at $37^{\circ} \mathrm{C}$. was approximately the same as? that of heparinized whole blood. The heparin used did not affect the rat colon preparation.

SEROTONIN IN CLOTS AND THROMBI In two dogs thrombi were formed by treatment of the intima of 3 the veins with phenol (Sabiston. Marshall, Dunnill. and Allison, 1962). The thrombi were removed one $\frac{\mathrm{O}}{3}$ week later and blood was taken at the same time for the preparation of fresh clots. Weighed portions of clot or thrombi were ground in a tissue homogenizer, $>$ made up to a known volume with saline, and assayed in the same manner as whole blood. The same method was used in the assay of serotonin in a. thrombus removed from a patient at embolectomy.

INJECTION OF BLOOD CLOT INTO NORMAL DOGS Blood was taken from the femoral vein of the normal (recipient) $d o g$ and the reserpine-treated dog. Frome each $\operatorname{dog} 20 \mathrm{ml}$. of blood was put into each of three $\mathbb{\Phi}$ tubes and allowed to clot. Blood samples were also ? taken for serotonin assay.

The normal dog was connected to a closed-circuit spirometer system, using a cuffed endotracheal tube. An oesophageal balloon was used to record intra- $\frac{\mathbb{D}}{\mathbb{D}}$ thoracic pressure changes. The intra-oesophageal $\frac{}{\sigma}$ pressure and the tidal volume trace from the spirometer were recorded from a double-beam oscillo- 8 
scope. A size 6 Cournand catheter, inserted into the pulmonary artery by way of the external jugular vein, was used to record pressures and also for giving drugs into the pulmonary artery. The catheter was kept flushed with normal saline; heparin was not used because of its possible action on release of serotonin from the clots (Cobb and Nanson, 1960). The reference level for zero pressure was the highest point of the sternum with the dog supine. An 18 gauge thinwalled needle was inserted into a leg vein for injection of the drugs or clot.

The static compliance of the chest and lungs of the dogs was measured by inflating the lungs to a pressure of 10 or $20 \mathrm{~cm}$. water and then turning a tap to connect the lungs to the spirometer circuit. From the continuous records of intra-oesophageal pressure and tidal volume the dynamic compliance of the lungs was measured by the method of v. Neergaard and Wirz (1927) and the non-elastic resistance of the lungs by drawing pressure-volume loops and calculating as described previously (Marshall and Allison, 1962).

Serotonin was given as serotonin creatinine sulphate, and in each case it was injected in a total volume of $5 \mathrm{ml}$. The doses given are expressed as the weight of the salt.

The usual procedure was (a) measurement of static compliance; $(b)$ injection of solutions of serotonin into the leg vein; and (c) injection of $20 \mathrm{ml}$. clot through the 18 gauge thin-walled needle into the leg vein. The normal and serotonin-depleted blood was given first in alternate experiments ; and $(d)$ injection of a further $20 \mathrm{ml}$. of clot. The procedures $(a)$ to $(d)$ were repeated until all six portions of clot had been given or until the dog died. The injections were given at approximately five-minute intervals. Recordings of tidal volume, intra-oesophageal pressure, and pulmonary arterial pressure were made at the time of each injection.

INJECTION OF BLOOD CLOT INTO SEROTONIN-DEPLETED DOGS The procedure was the same as for the normal dogs, but the dog's own (serotonin-depleted) blood only was used for the formation of clots.
T A B L E I

SEROTONIN ESTIMATIONS AND PLATELET COUNTS

\begin{tabular}{|c|c|c|c|c|c|c|}
\hline \multirow{3}{*}{$\begin{array}{l}\text { Reci- } \\
\text { pient } \\
\text { Dog }\end{array}$} & \multicolumn{3}{|c|}{ Serum Serotonin $(\mu \mathrm{g} . / \mathrm{ml})}$. & \multicolumn{3}{|c|}{ Platelets $\times 10^{5}, \mathrm{c} . \mathrm{mm}$. } \\
\hline & \multicolumn{2}{|c|}{ Donor } & \multirow{2}{*}{$\begin{array}{l}\text { Reci- } \\
\text { pient }\end{array}$} & \multicolumn{2}{|c|}{ Donor } & \multirow{2}{*}{$\begin{array}{l}\text { Reci- } \\
\text { pient }\end{array}$} \\
\hline & $\begin{array}{c}\text { Before } \\
\text { Reserpine }\end{array}$ & $\begin{array}{c}\text { After } \\
\text { Reserpine }\end{array}$ & & $\begin{array}{c}\text { Before } \\
\text { Reserpine }\end{array}$ & $\begin{array}{c}\text { After } \\
\text { Reserpine }\end{array}$ & \\
\hline $\begin{array}{l}1 \\
2 \\
3 \\
4 \\
5 \\
6 \\
7 \\
8\end{array}$ & $\begin{array}{l}0.7 \\
1.0 \\
0.7 \\
1.5 \\
0.5 \\
0.6 \\
0.8 \\
0.8\end{array}$ & $\begin{array}{l}0 \\
0 \\
0 \\
0 \cdot 03 \\
0 \cdot 21 \\
0 \cdot 04 \\
0 \\
0\end{array}$ & $\begin{array}{l}1 \cdot 1 \\
\cdot .1 \\
1.0 \\
2.5 \\
0.6 \\
0.8 \\
1.2 \\
1.3\end{array}$ & $\begin{array}{l}3 \cdot 7 \\
2 \cdot 0 \\
4 \cdot 7 \\
3 \cdot 1 \\
1.1 \\
3 \cdot 1 \\
0.7 \\
2 \cdot 0\end{array}$ & $\begin{array}{l}3 \cdot 4 \\
3 \cdot 7 \\
2 \cdot 6 \\
2 \cdot 2 \\
3 \cdot 2 \\
2 \cdot 6 \\
2 \cdot 4\end{array}$ & $\begin{array}{l}4.4 \\
1.7 \\
2.3 \\
3.3 \\
1.9 \\
3.0 \\
3.3 \\
2.3\end{array}$ \\
\hline \multicolumn{7}{|c|}{$\begin{array}{l}\text { Serotonin-depleted dogs } \\
9 \\
10 \\
11\end{array} \mid \begin{array}{r}<0.05 \\
0.02 \\
<0.05\end{array}$} \\
\hline
\end{tabular}

1 This serum contained a slowly reacting substance not inactivated by promethazine which prevented the action of serotonin.

\section{RESULTS}

Alternate clots of normal and serotonin-depleted blood were given to eight dogs; in five of these the normal clot was given first and in the remaining three the serotonin-depleted clot was given first. The serotonin content of the serum is shown in Table $I$.

Of the eight dogs, four survived the injection of six lots of $20 \mathrm{ml}$. of clots (Table II). Four dogs were killed by the injections of clot; two died after the fourth injection, and two after the fifth injection. It is probably of no significance that the final injection of clot which led to the death of the four dogs was in all cases clot made from serotonin-depleted blood. The effect of the injections on the pulmonary arterial pressure and non-elastic resistance of two of the dogs is shown in Figures 1 and 2. Figure 2 shows the response in a dog in which, although the pulmonary arterial pressure rose more after injection of normal clot, death followed an injection of serotonin-depleted clot.

T A B L E I I

RESULTS OF INJECTION OF CLOTS

\begin{tabular}{|c|c|c|c|c|c|c|c|c|}
\hline \multirow[b]{2}{*}{ Dog } & \multirow[b]{2}{*}{$\begin{array}{c}\text { Weight } \\
\text { (kg.) }\end{array}$} & \multirow[b]{2}{*}{$\begin{array}{l}\text { Initial Pulm. } \\
\text { Artery Pressure } \\
\text { (mm. Hg) }\end{array}$} & \multirow[b]{2}{*}{$\begin{array}{l}\text { Clot } \\
\text { Given } \\
\text { First }\end{array}$} & \multirow[b]{2}{*}{$\begin{array}{l}\text { No. of } \\
\text { Clots }\end{array}$} & \multicolumn{2}{|c|}{ Serotonin-depleted Clots } & \multicolumn{2}{|c|}{ Normal Clots } \\
\hline & & & & & Respiration 1 & $\begin{array}{l}\text { Max. Pulm. } \\
\text { Artery Pressure } \\
\text { (mm. Hg) }\end{array}$ & Respiration ${ }^{1}$ & $\begin{array}{l}\text { Max. Pulm. } \\
\text { Artery Pressure } \\
\text { (mm. Hg) }\end{array}$ \\
\hline $\begin{array}{l}1 \\
2 \\
3 \\
4 \\
5 \\
6 \\
7 \\
8\end{array}$ & $\begin{array}{l}14 \cdot 2 \\
12.5 \\
12.5 \\
10.8 \\
14 \cdot 2 \\
13.6 \\
14.2 \\
14.8\end{array}$ & $\begin{array}{c}11 /-2 \\
13 /-3^{2} \\
20 / 8 \\
25 / 5 \\
13 / 5 \\
9 / 0 \\
6 / 0 \\
12 / 0\end{array}$ & $\begin{array}{l}\mathbf{N} \\
\mathbf{N} \\
\mathbf{R} \\
\mathbf{N} \\
\mathbf{R} \\
\mathbf{N} \\
\mathbf{R} \\
\mathbf{N}\end{array}$ & $\begin{array}{l}6 \text { (S) } \\
5 \text { (D) } \\
5 \text { (D) } \\
4 \text { (D) } \\
6 \text { (S) } \\
6 \text { (S) } \\
6 \text { (S) } \\
4 \text { (D) }\end{array}$ & $\begin{array}{c}n \\
3=r s \\
5=r d \\
\text { All rs } \\
\text { All rs } \\
6=r s \\
3,5=\text { rs } \\
4=r s\end{array}$ & $\begin{array}{c:c}102 / 37 \\
40 & -1^{2} \\
80 / 72 \\
85 & 36 \\
80 & 32 \\
107 & 43 \\
43 / 29 \\
76 / 37\end{array}$ & $\begin{array}{c}5=\mathrm{rd} \\
5=\mathrm{rd} \\
5=\mathrm{rd} \\
\text { All rs } \\
\text { All rs } \\
\quad \mathrm{n} \\
\begin{aligned} 6=\mathrm{rs} \\
3=\mathrm{rs}\end{aligned}\end{array}$ & $\begin{array}{c}120 / 33 \\
48 / 4^{2} \\
75 / 6^{2} \\
78 / 51 \\
80 / 38 \\
67 / 32 \\
37 / 23 \\
75 / 32\end{array}$ \\
\hline
\end{tabular}

N, normal; R, reserpine-treated (serotonin-depleted); S, survived; D, died. rd, rapid and deep.

2 Right ventricular pressures. 


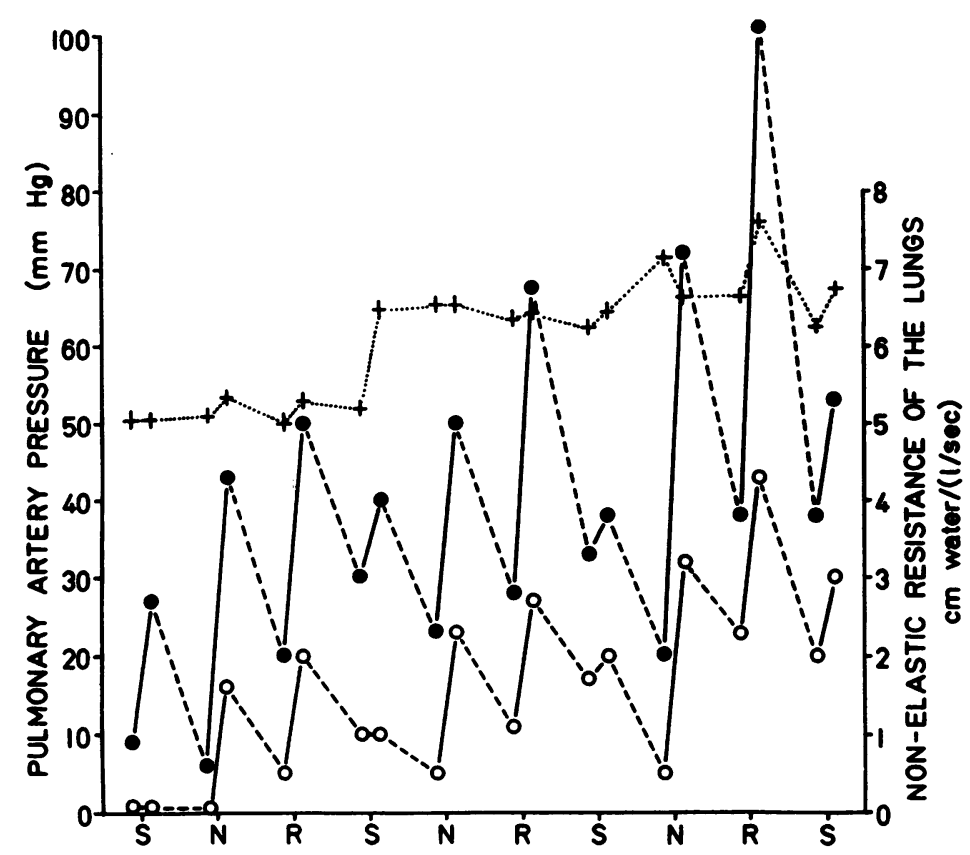

FIG. 1. Dog 6. The effect on pulmonarg arterial pressure and the non-elastic res sistance of the lungs of the injection of 100 $\mu g$. of serotonin $(S)$, normal blood clat $(N)$, and serotonin-depleted clot $(R)$ , Systolic pulmonary arterial pressurg $\bigcirc$, diastolic pulmonary arterial press: ure; + , non-elastic resistance of the lungs. The values shown are those ins mediately before the injection and tho maximum value reached after the injection

A comparison has been made of the pulmonary arterial pressure reached after injection of clots in six of the dogs, three of which had the normal clot first and three the serotonin-depleted clot first. Since not all the dogs received six clots, only the effect of the first four clots has been considered. The mean systolic and diastolic pulmonary arterial pressures after the injection of normal clots were 49 (S.D. 19) and 28 (S.D. 9) $\mathrm{mm}$. $\mathrm{Hg}$ respectively, and after the injection of serotonindepleted clots 45 (S.D. 22) and 24 (S.D. 14) mm. $\mathrm{Hg}$ respectively. The difference between these values is not significant (S.E. of the difference of means 8.5 and $8.4 \mathrm{~mm}$. $\mathrm{Hg}$ for the systolic and diastolic pressures respectively).

The change in non-elastic resistance after the injection of clots was variable but usually small. Increases of up to $100 \%$ were recorded, but in some cases the non-elastic resistance decreased after the injection of clot. In the six dogs compared above the mean increase in non-elastic resistance after injection of normal clot was $12 \%$ and after the injection of serotonin-depleted clot $7 \%$. As has been noted before (Marshall and Allison, 1962), the incidence of rapid shallow breathing after the injection of clots was variable (Table II). It was seen more commonly after several clots had been injected, but in some dogs it was produced by each injection of clots. It was not related to changes in non-elastic resistance or

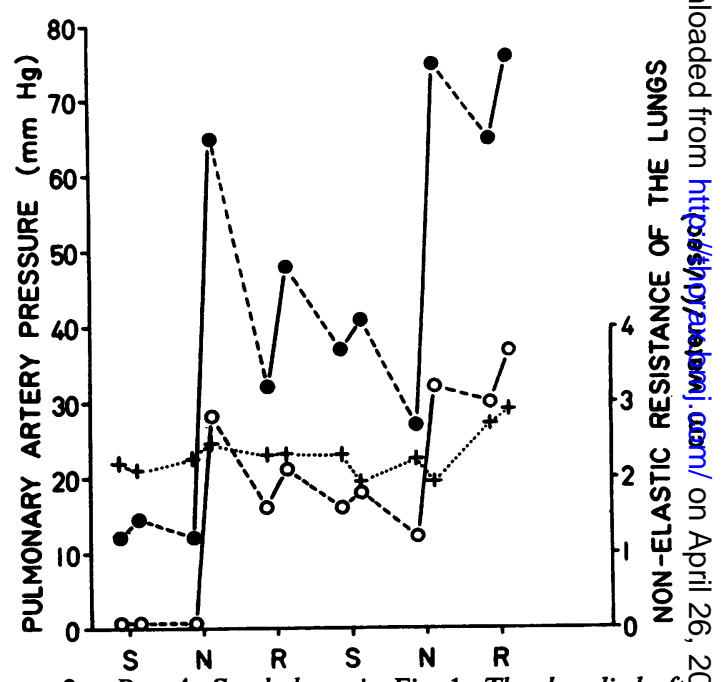

FIG. 2. Dog 4. Symbols as in Fig. 1. The dog died afteo the fourth injection of clot.

compliance, and the dog with the most markeg rapid shallow respiration showed a small decreas in non-elastic resistance after the injection of clow

Changes in the resting expiratory level wer seen in only three dogs. Dog 1 decreased the lung volume at the resting expiratory level by aboug $160 \mathrm{ml}$. after clot 5 ; there was no change aftein clot 6. Dog 3 decreased the lung volume at the resting expiratory level by about $140 \mathrm{ml}$. after 
T A B LE II I

INJECTION OF CLOTS INTO SEROTONIN-DEPLETED DOGS

\begin{tabular}{|c|c|c|c|c|c|c|c|c|}
\hline \multirow{2}{*}{ Dog } & \multirow{2}{*}{$\begin{array}{l}\text { Weight } \\
\text { (kg.) }\end{array}$} & \multirow{2}{*}{$\begin{array}{l}\text { Clot } \\
\text { No. }\end{array}$} & \multirow{2}{*}{ Respiration } & \multicolumn{2}{|c|}{$\begin{array}{l}\text { Pulm. Artery Pressure } \\
(\mathrm{mm} . \mathrm{Hg})\end{array}$} & \multirow{2}{*}{$\begin{array}{c}\text { Initial } \\
\text { Femoral Artery } \\
\text { Pressure } \\
\text { (mm. Hg) }\end{array}$} & \multirow{2}{*}{$\begin{array}{c}\text { Non-elastic } \\
\text { Resistance } \\
\text { Change } \\
(\%)\end{array}$} & \multirow{2}{*}{$\begin{array}{l}\text { Compliance } \\
\text { Change }(\%)\end{array}$} \\
\hline & & & & Initial & Final & & & \\
\hline 9 & 15.0 & $\begin{array}{l}1 \\
2 \\
3 \text { (D) }\end{array}$ & $\begin{array}{l}\text { (rs) } \\
\text { rs }\end{array}$ & 80 & 3020 & & -11 & +20 \\
\hline 10 & $13 \cdot 8$ & $\begin{array}{l}1 \\
2 \\
3 \\
4 \\
5 \\
6(S)\end{array}$ & $\begin{array}{c}\text { rs } \\
\text { (rs) }\end{array}$ & 100 & 4223 & 11580 & +15 & $\begin{array}{l}+29 \\
+20 \\
+40\end{array}$ \\
\hline 11 & $12 \cdot 5$ & $\begin{array}{l}1 \\
2 \\
3 \\
4 \text { (D) }\end{array}$ & $\begin{array}{l}\mathbf{r} \\
\mathbf{l}\end{array}$ & 70 & 44,24 & 10072 & & \\
\hline
\end{tabular}

rs, rapid shallow breathing; parentheses denote a weak response; r, rapid breathing; $D$, died; S, survived.

Changes in non-elastic resistance and compliance are shown only when they exceeded $10 \%$. The changes lasted for a few breaths only.

clots 4 and 5 , and dog 8 decreased the resting expiratory level by about $50 \mathrm{ml}$. after clot 4 . In each instance when the resting expiratory level decreased there was no appreciable (less than $10 \%$ ) increase in the non-elastic resistance of the lungs.

In seven of the dogs, injections of serotonin were given after each two injections of clot. In two of the dogs, $200 \mu \mathrm{g}$. of serotonin, and in the remainder $100 \mu \mathrm{g}$. of serotonin, were given. After the injection of these doses of serotonin there was usually a small or moderate increase in pulmonary artery pressure (Figs 1 and 2), but smaller than that resulting from the injection of $20 \mathrm{ml}$. of clot. Serotonin did not cause a larger rise in pulmonary artery pressure when the lungs contained blood clot. The response of the non-elastic resistance to injections of serotonin was as variable as it was to the injection of clots. Occasional injections increased the non-elastic resistance transiently by about $100 \%$, but it was often decreased, and in the six dogs analysed above the mean increase in non-elastic resistance after serotonin was $7 \%$.

Changes in dynamic compliance after injections of clot or serotonin were less than $10 \%$ except after the third injection of clots in dog 2 , when for a few breaths the compliance was decreased by $25 \%$, and after an injection of serotonin in $\operatorname{dog} 4$, when the compliance decreased by about $40 \%$. The changes in static compliance of the lungs and chest wall measured between injections were less than $10 \%$ in all cases while the dog was breathing. In four of the dogs the static compliance was measured soon after the onset of the terminal apnoea, and in each of these dogs the compliance had decreased by about $30 \%$. Since there was no change in lung compliance up to the time of apnoea the decrease in compliance of lungs and chest wall combined was most probably due to increased tone of the muscles of the chest wall.

Serotonin-depleted blood clots were injected into serotonin-depleted dogs in three experiments, and the results are shown in Table III. The serotonin content of the blood is shown in Table $I$. These reserpine-treated dogs breathed more slowly than usual, and the 'rapid, shallow' breathing which occurred was less rapid than in normal dogs. Injections of serotonin were also given in these dogs and the response was no different from that in the normal dogs; the injections usually produced a small transient rise in pulmonary artery pressure and sometimes a small rise in nonelastic resistance which lasted for only a few breaths.

The results of assay of serotonin in blood clot and thrombi are shown in Table IV. The serotonin content of the clots did not change appreciably in clots incubated at $37^{\circ} \mathrm{C}$. and separated after periods varying from half to five hours, and the serotonin content of the clots was almost the same as that of whole blood. One-week-old thrombi contained three to four times more serotonin than the fresh clots, and the assay on thrombi removed from the pulmonary artery of a patient at operation showed that the emboli con-

T A B LE IV

THE SEROTONIN CONTENT OF CLOTS AND THROMBI

\begin{tabular}{c|c|c}
\hline \multirow{2}{*}{ Dog } & \multicolumn{2}{|c}{ Serotonin $(\mu \mathrm{g} . / \mathrm{g})}$. \\
\cline { 2 - 3 } & Clot & Thrombus \\
\hline A & $0 \cdot 8$ & $3 \cdot 5$ \\
$1 \cdot 2$ & $3 \cdot 1$ \\
\hline Human patient H.C. & Red thrombus, 2.8 & White thrombus, 6.0 \\
\hline
\end{tabular}


tained more serotonin than is usually present in whole blood.

\section{DISCUSSION}

Injections of either serotonin or blood clot cause a rise in pulmonary artery pressure and sometimes an increase in non-elastic resistance in anaesthetized dogs and other mammals. Since blood platelets normally contain serotonin which is released by the processes of clotting it seems possible that some, at least, of the physiological effects of pulmonary embolism may be due to the action of serotonin or of a substance liberated by serotonin (Nelson and Smith, 1959). Smith and Smith (1955) found that in cats anaesthetized with chloralose serotonin produced effects similar to those produced by fragmented blood clot. The effects of both serotonin and blood clot were antagonized by dibenylene but not by atropine or mepyramine, so it was concluded that the effects were not mediated through acetylcholine or histamine. This may be insufficient evidence on which to discount the action of histamine, for barium sulphate embolization appears to cause bronchoconstriction by histamine liberation even though the effect is not blocked by antihistamines (Nadel, Colebatch, and Olsen, 1964).

Cobb and Nanson (1960) observed similar effects of serotonin and fresh blood clots in anaesthetized dogs, and they noted that heparin, which inhibits the release of serotonin from platelets, exerted a protective effect on dogs injected with blood clot. The protective effect of heparin was observed after the infusion of serotonin. Thomas. Stein, Tanabe, Rege, and Wessler (1964) have reported that heparin prevents the bronchoconstrictor response which normally occurs when autologous venous thrombi impact in the lungs. Heparin has no anti-serotonin effect in vitro (Thomas et al., 1964; Marshall, unpublished observations), but if, as claimed by Knisely, Wallace, and Addison (1958), serotonin causes intravascular agglutination of platelets, then heparin may be able to prevent a secondary release of serotonin from the platelet agglutinates.

Nemir, Stone, Mackrell, and Hawthorne (1954) were unable to produce effects equivalent to those of pulmonary embolism by injection of serotonin or histamine into a blocked pulmonary artery. A repetition of these experiments (Marshall, to be published) has shown that $100 \mu \mathrm{g}$. of serotonin, a quantity greater than would be present in most blood thrombi, has no respiratory or cardiovascular effect when injected in a volume of $5 \mathrm{ml}$. into a blocked pulmonary artery.
Pulmonary embolization causes no measurable increase in serotonin in the systemic blood (Sanders, Waalkes, Gilbert, and Terry, 1959), but the amount of serotonin which had to be injected intravenously to produce a measurable increase in systemic serotonin produced a much greater rise in pulmonary artery pressure than is usually is caused by embolization. Sanders et al. (1959) have $\vec{\circ}$ reported that the lungs of $\mathrm{dog}$, cat, and man contain no serotonin, so that release of serotonin from the lung tissues cannot be the cause of any respiratory or cardiovascular effects.

The series of experiments reported here suggest that serotonin plays either no, or only a small, part $\omega$ in the response of anaesthetized dogs to emboliza- No tion with blood clot. Clots depleted of serotonin o produce the same effect as clots containing the $\mathrm{O}$ normal amount of serotonin. Serotonin-depleted $\overrightarrow{ }$ dogs are killed just as easily by clots of their own blood as are normal dogs. It is possible that reserpine-treated dogs were more easily killed by $\vec{\oplus}$ blood clot than were normal dogs, but the numbers were too small for any definite conclusion to be made on this point. The initial blood pressure was $\sum^{\circ}$ low in the two resperine-treated dogs in which it was measured, and the pulmonary arterial pressure in the two dogs which died was lower than in $\mathbb{D}$ normal dogs which died as a result of embolization. State and Salisbury (1956) found pulmonary 음 embolism to be universally fatal in hypotensive dogs, although Mann (1917) reported that dogs with a low blood pressure due to prolonged anaesthesia or distemper reacted no differently from normal dogs.

The effect of reserpine on the response of rats ${ }_{0}^{x}$ to embolization with lycopodium spores was studied by Frick (1959). Reserpine-treated rats survived pulmonary embolism more easily than $\frac{3}{3}$ control rats. There was no record of the bloodo pressure at the time of embolization and no evidence to suggest that the increased survival $\frac{D}{0}$ after reserpine was due to its serotonin-depleting effect.

Although serotonin has a bronchoconstrictor $\mathrm{N}$ action it is a relatively weak one in man. It has N no constrictor action on isolated human bron- $\omega$ chiolar muscles (Brocklehurst, 1958) and its bronchoconstrictor effect when given intravenously을 to normal man is also small (Stone, Horiguchi. Donnelly, and Nemir, 1961 ; Michelson, Hollander, and Lowell, 1958). In the experiments reported here the effects of serotonin on both the pul- $\overrightarrow{\mathbb{D}}$ monary artery pressure and the non-elastic resist- $\frac{?}{0}$ ance were similar to those reported by Rose and $\varrho$ Lazaro (1958). These authors too found that smallo doses of serotonin $(1.5$ to $47 \mu \mathrm{g} . / \mathrm{kg}$.) produced an $\delta$ 
appreciable rise in pulmonary artery pressure but either no (no response in 28 of 64 injections) or only a small (less than $25 \%$ ) increase in nonelastic resistance of the lungs. Such doses of serotonin, although small, are larger than the amount which might be present in a thrombus lodged in the pulmonary artery.

The composition of a pulmonary embolus may be very variable. If it consists of blood which has clotted in an obstructed vessel it will contain only the same quantity of platelets, and therefore the same serotonin content, as whole blood. In man it would contain about $0 \cdot 2 \mu \mathrm{g} . / \mathrm{ml}$. (Humphrey and Jaques, 1954 ; Sanders et al., 1959) or $2 \mu \mathrm{g}$. serotonin in a $10 \mathrm{ml}$. clot. A white thrombus contains many more platelets than a blood clot, but it is probable that most of the serotonin is released from the platelets as they are laid down in the thrombus. The serotonin content of thrombi (Table IV) is higher than that of whole blood, and a large thrombus in man may contain about 100 $\mu \mathrm{g}$. of serotonin, but the injection of $100 \mu \mathrm{g}$. of serotonin into a blocked pulmonary artery of a dog produced no change in respiratory rhythm or in non-elastic resistance of the lungs.

Previous experiments on dogs (Marshall and Allison, 1962 ; Marshall, Sabiston, Allison, Bosman, and Dunnill, 1963) have shown that emboli of small, fresh blood clots produce greater changes in respiratory rhythm and in the mechanical properties of the lungs than do large thrombi. The volume of the thrombus used was only about one-third that of the clots given at each injection, but the serotonin content was probably of the same order.

It has been reported that anaesthesia modifies the effect of pulmonary embolism in rabbits, rats, and guinea-pigs (Byrne, 1955 ; Frick, 1959 ; Sternberg and Tamari, 1928), and it may do so in dogs and man. An investigation of the effects of serotonin, histamine, and small blood clots in unanaesthetized dogs and in dogs anaesthetized with different types of anaesthetic is at present in progress.

\section{SUMMARY}

Experiments have been carried out on anaesthetized dogs to investigate the role of serotonin in pulmonary embolism by blood clot.

Blood clots, free of serotonin, were obtained from dogs treated with reserpine. The effect of pulmonary embolism on respiration, on the mechanical properties of the lungs, or on pulmonary haemodynamics, and the lethal dose of clot, was not affected by the presence or absence of serotonin in the clots used as emboli.

\section{REFERENCES}

Brocklehurst, W. (1958). The action of 5-hydroxytryptamine on smooth muscle, In 5-Hydroxytryptamine, p.172, ed. G. P. Lewis. London, Pergamon Press.

Byrne, J. J. (1955). Vagus nerve and pulmonary embolism. Arch. Surg., 70, 111 .

Cobb, B., and Nanson, E. M. (1960). Further studies with serotonin and experimental pulmonary embolism. Ann. Surg., 151, 501.

Comroe, J. H., Van Lingen, B., Stroud, R. C., and Roncoroni, A. (1953). Reflex and direct cardiopulmonary effects of 5-OHtryptamine (serotonin). Their possible role in pulmonary embolism and coronary thrombosis. Amer. J. Physiol., 173, 379.

Frick, M. H. (1959). The effect of reserpine pre-treatment in experimental pulmonary embolism. Ann. Med. exp. Biol. Fenn., 37, 290.

Haverback, B. J., Dutcher, T. F., Shore, P. A., Tomich, E. G., Terry, L. L., and Brodie, B. B. (1957). Serotonin changes in platelets and brain induced by small daily doses of reserpine. Lack of effect of depletion of platelet serotonin on hemostatic mechanisms. of depletion of platelet serot
New Engl. J. Med., 256, 343.

Humphrey, J. H., and Jaques, R. (1954). The histamine and serotonin content of the platelets and polymorphonuclear leucocytes of various species. J. Physiol. (Lond.), 124, 305.

- and Toh, C. C. (1954). Absorption of serotonin (5-hydroxytryptamine) and histamine by dog platelets. Ibid., 124, 300.

Knisely, W. M., Wallace, J. M., and Addison, W. A. (1958). "Temporary" pulmonary embolization caused by intravenous injecporary" pulmonary embolization caused by int

Mann, F. C. (1917). Pulmonary embolism. An experimental study. J. exp. Med., $26,387$.

Marshall, R., and Allison, P. R. (1962). Pulmonary embolism by small blood clots. Thorax, 17, 289.

Sabiston, D. C., Allison, P. R., Bosman, A. R., and Dunnill, M. S. (1963). Immediate and late effects of pulmonary embolism by large thrombi in dogs. Ibid., 18, 1 .

Michelson, A. L., Hollander, W., and Lowell, F. C. (1958). The effect of 5-hydroxytryptamine (serotonin) on the respiration of nonasthmatic and asthmatic subjects. J. Lab. clin. Med., 51, 57.

Nadel, J. A., Colebatch, H. J. H., and Olsen, C. R. (1964). Location and mechanism of airway constriction after barium sulfate micro-embolism. J. appl. Physiol., 19, 387.

Nasmyth, P. A and Stewart, H. C. (1950). The release of histamine by opium alkaloids. J. Physiol. (Lond.), 111, 19P.

v. Neergaard, K., and Wirz, K. (1927). İ ber eine Methode zur Messung der Lungenelastizität am lebenden Menschen, insbesondere beim Emphysem. Z. klin. Med., 105, 35.

Nelson, J. R., and Smith, J. R. (1955). The pathologic physiology of pulmonary embolism. A physiologic discussion of the vascular reactions following pulmonary arterial obstruction by emboli of varying size. Amer. Heart J., 58, 916.

Nemir, P., Stone, H. H., Mackrell, T. N., and Hawthorne, H. R. (1954). Studies on pulmonary embolism utilizing the method of controlled unilateral pulmonary artery occlusion. Surg. Forum, $\mathbf{5}, 210$.

Rose, J. C., and Lazaro, E. J. (1958). Pulmonary vascular responses to serotonin and effects of certain serotonin antagonists. Circulat. Res., 6, 283.

Sabiston, D. C., Marshall, R., Dunnill, M. S., and Allison, P. R. (1962). Experimental pulmonary embolism: description of a method utilizing large venous thrombi. Surgery, 52, 9.

Sanders, R., Waalkes, T. P., Gilbert, J. W., and Terry, L. L. (1959). Serotonin (5-hydroxytryptamine) and pulmonary thromboembolism. Surg. Gynec. Obstet., 109, 455.

Shore, P. A., Pletscher, A., Tomich, E. G., Carlsson, A., Kuntzman, R., and Brodie, B. B. (1957). Role of brain serotonin in reserpine action. Ann. N.Y. Acad. Sci., 66, 609.

Smith, G., and Smith, A. N. (1955). The role of serotonin in experimental pulmonary embolism. Surg. Gynec. Obstet., 101, 691.

State, D., and Salisbury, P. F. (1956). The experimental production of the pulmonary embolism syndrome and the effects of variations the pulmonary embolism syse on its course. Ibid., 103, 202.

Sternberg, H., and Tamari, M. (1928). Über den Einfluss der funktionellen Narkose und mechanischen Hirnausschaltung auf die Lungenkapillaren. Naunyn-Schmiedeberg's Arch. exp. Path. Pharmak., 136, 34.

Stone, H. H., Horiguchi, S., Donnelly, C. C., and Nemir, P. (1961). Changes in plasma serotonin concentration in the surgical patient: its possible significance. Surg. Forum, 12, 140.

Thomas, D., Stein, M., Tanabe, G., Rege, V., and Wessler, S. (1964). Mechanism of bronchoconstriction produced by thromboemboli in dogs. Amer. J. Physiol., 206, 1207. 